\title{
The Sergeant John R. Rice Incident and the Paradox of Indian Civil Rights
}

\author{
THOMAS A. BRITTEN AND LARRY W. BURT
}

ON A WARM HUMID MORNING in late August 1951, Evelyn Rice, her three young children, and dozens of other Rice family members and friends gathered at Memorial Park Cemetery on the southeast side of Sioux City, Iowa. The occasion was to pay last respects to Evelyn's husband, John R. Rice, a decorated army soldier who had been killed in action while serving in the Korean War. Following a Catholic graveside service, members of two American Legion posts conducted a brief military ceremony. After the playing of taps, the grieving family returned home to nearby Winnebago, Nebraska, exhausted but relieved that their loved one had finally been laid to rest. Unbeknownst to them as they drove the 25-mile stretch southwest to Winnebago, events were unfolding back at the cemetery that would reignite their grief, stun the surrounding region, and provoke anger and disbelief across the country. The events even caught the attention of President Harry S. Truman and prompted his direct intervention on behalf of the Rice family.

When placed within the broader context of post-World War II America, the John Rice incident sheds light on important issues that Americans confronted during the Truman presidency. Two key concerns were the Cold War and the burgeoning civil rights movement, seemingly disparate matters that overlapped and influenced each other as the United States struggled to expand its democratic ideals at home and abroad. The John Rice incident also indicates an important juncture in the post-World War II

THE ANNALS OF IOWA 63 (Summer 2004). (c) The State Historical Society of Iowa, 2004. 
American Indian civil rights movement, demonstrating how the campaign for Indian civil rights got caught up in the sweep of the much broader civil rights movement of the 1950s. Most nonIndians in the 1940s and 1950s mistakenly perceived Indians as seeking the same goals of winning full rights of U.S. citizenship that other minorities fought for.

Comparisons of Indian civil rights to those of African Americans had become commonplace in the years after World War II, making it easy to overlook the differences between Indians and other racial minorities. Moreover, for decades Indian issues had received scant national attention and had been pushed further and further into the background as the United States became a superpower with complicated interests all around the globe. Only later did many come to understand that civil rights sometimes meant different things to different people. For Indians, tribal rights based on separate sovereignty were just as important as individual rights.

JOHN R. RICE (Walking in Blue Sky) was an American Indian, a member of the Winnebago (Ho Chunk) Nation of northeastern Nebraska. Born on April 25, 1914, and raised in the tiny town of Thurston on the southwestern edge of the Winnebago reservation, Rice lived in a time and place in which being Indian limited options and opportunities in life. There was little to encourage a strong identification with an Indian heritage. While growing up, he attended off-reservation boarding schools that pulled him far away from the reservation and the Indian community. As a young man during the early years of the Great Depression, the only employment to be found around the reservation was intermittent farm labor. John Rice thus had little experience with traditional Ho Chunk life, and he never felt a part of the reservation community. ${ }^{1}$

On December 26, 1941, the 26-year-old Rice enlisted in the army, just weeks after the Japanese attack on Pearl Harbor. It was a dangerous time to be in uniform. The armies of Nazi Germany were establishing their dominance in Europe while

1. Pam Rice Goodwin (daughter of Sgt. John R. Rice), telephone interview with Larry W. Burt, 9/20/2000. 
their Axis ally, Japan, was seeking to do the same in China and Southeast Asia. Like many of the approximately 25,000 American Indians who served in the military during World War II, Rice was introduced to a very different world. The army gave him a steady income and an escape from a life that afforded him little opportunity. Early in 1942, Rice headed west into the Pacific theater. For the next three-and-a-half years, he saw duty in New Guinea and the Philippines while serving with the famed Thirty-second Infantry ("Red Arrow") Division.

Following his discharge from the army in October 1945, Rice returned briefly to civilian life to recuperate both mentally and physically from the rigors of war. Periodically he worked construction jobs, trying to make a living for himself and his new bride, Evelyn, a local farmer's daughter and a Caucasian he had married while home on furlough in February 1945. Happy to be out of the army but frustrated again by a lack of economic opportunities on the reservation, Rice reenlisted in January 1946. For the next few years he fulfilled his military obligation in the peacetime army at Fort Carson, Colorado, in Korea, and at Fort Sheridan, Illinois. For a while he served as a member of an army escort unit that accompanied the bodies of war dead being returned stateside for burial. ${ }^{2}$

After North Korea invaded South Korea on June 25, 1950, President Truman ordered U.S. troops to respond. The ensuing three months pitted American soldiers, fighting alongside their United Nations allies, against a determined North Korean adversary. In late August John Rice, now a first sergeant serving with Company A, Eighth Regiment, First Cavalry Division, arrived in Korea. The military situation appeared desperate. American-led forces clung tenuously to the "Pusan perimeter" in the southeast corner of the peninsula; another major North Korean offensive might force unification of the two Koreas. On

2. Ibid; "Soldier's Burial," Time, 9/10/1951, 26; "Sergeant Rice, U.S.A.," New York Times, 9/2/1951, sec. 4; Arlington National Cemetery, "John R. Rice," www.arlingtoncemetery.net/jrrice.htm; William L. Hewitt, "The Indian Who Never Got Home," Nebraska History 77 (1996), 12-13. Rice's postwar plight of little opportunity and few good choices was all too common among Indian veterans. See Kenneth William Townsend, World War II and the American Indian (Albuquerque, NM, 2000), 215-18. 


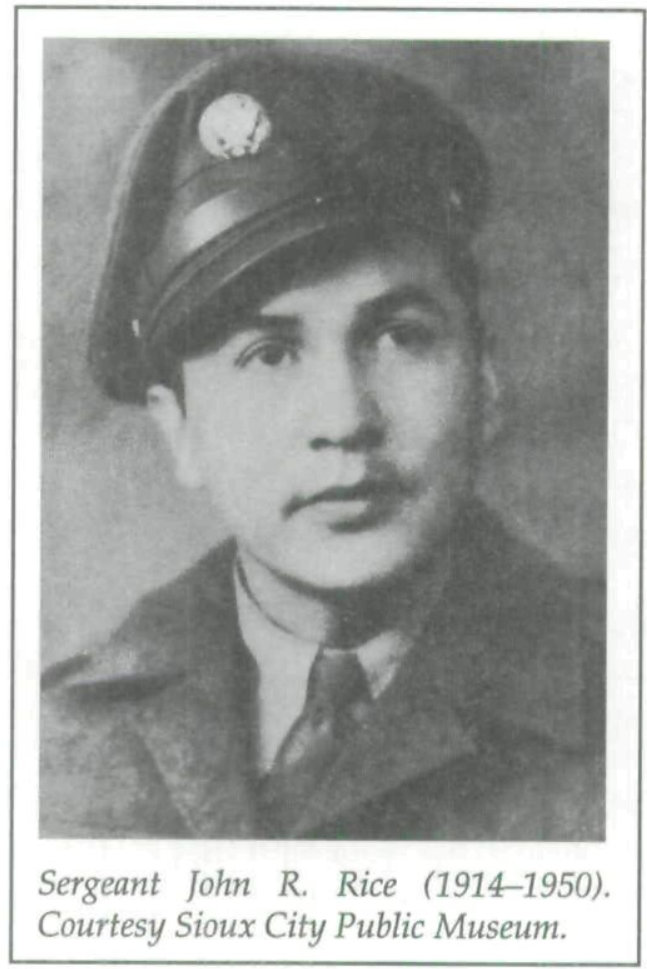

September 6, as the First Cavalry fought to slow the North Korean advance, 37-year-old John Rice was killed in action while leading a squad of riflemen in a desperate effort to hold the Naktong River bridgehead a few miles north of the village of Taegu (Tabu-Dong). He was one of 307 Nebraska servicemen killed during the conflict. ${ }^{3}$

The army took nearly a year to arrange for the transport home of Rice's body. ${ }^{4}$ Shortly before the deceased arrived state-

3. "Truman Sets Arlington Internment for Indian Denied 'White' Burial," New York Times, 8/30/1951; "Indian Hero Is Buried in Arlington Ceremony after Being Refused Internment in Sioux City," New York Times, 9/6/1951; John R. Rice Casualty File, RG 407: Records of the Adjutant General's Office, Korean War Casualty File, 2/13/1950-12/31/1953, National Archives, Washington, DC. 507 Iowans were killed in the Korean War. See www.archives.gov/research_ room/research_topics/korean_war_casualty_lists/ia_by_town.html.

4. This was not unusual. Thousands of men killed during World War II and the Korean Conflict were buried in temporary cemeteries near the battlefield until the war was over or recovery of remains was more easily accomplished. During the Korean Conflict, helicopters were used for the first time to retrieve the dead 
side, military officials notified Evelyn Rice that she needed to make final arrangements for her husband. In mid-August 1951, therefore, Evelyn and her sister Thelma (who was married to Henry Rice-John's older brother) drove to Sioux City, where they met with Ben Willey, sales manager for Memorial Park Cemetery, a private facility with "beautiful, well-cared for grounds." They discussed a graveside service, and Evelyn Rice signed the necessary paperwork to purchase three lots. She failed to notice a clause in the contract that restricted burial in Memorial Park to "members of the Caucasian race." Ben Willey, meanwhile, did not realize that the deceased was an Indian (even though he knew that the Rice family lived on the Winnebago reservation), and he did not think to verbally inform her of the restriction. It was not until after the August 28 funeral service that both Evelyn Rice and cemetery officials discovered their "mistake."

As the mourners filed out of the cemetery following the graveside service, Willey, in a conversation with funeral home director Dalton T. Boyd, commented that he had been surprised to see so many Indians at the burial ceremony. Ten of the twelve honor guardsmen from the American Legion post in attendance at the funeral, for example, had been American Indians. Boyd replied by asking, didn't Willey know that John Rice was a Winnebago Indian? Shocked, Willey quickly related the news to J. M. Gunnell, the secretary-treasurer of Memorial Park. Gunnell, in turn, called a halt to the burial and ordered that Sergeant Rice's body, which had rested above the open grave for nearly five hours, be returned to Barber-Boyd Funeral Home in South Sioux City, Nebraska. Funeral home officials then drove out to Winnebago to deliver the unwelcome news that the Rice family would need to make new arrangements for John. ${ }^{6}$

so they could be shipped home more quickly. See Dan Baum, "Two Soldiers: How the Dead Come Home," New Yorker, 8/9 and 8/16/2004, 79-80.

5. "The Truth about the Sergeant Rice Incident," pamphlet produced by Memorial Park Cemetery, Official File, Harry S. Truman Papers, Harry S. Truman Presidential Library, Independence, MO; Hewitt, "The Indian Who Never Got Home," 13.

6. "The Truth about the Sergeant Rice Incident"; Sioux City Journal, 8/29 and 8/30/1951; Harry Ross, "The Indian Who Never Got Home," UAW Fair Practices and Anti-Discrimination Department, 1/4/1952, 5-7. 
Over the course of the next 24 hours, what had started out as the simple burial of an American war hero escalated into a national incident. When cemetery officials halted the burial, Master Sergeant John C. Boles, a member of the Army Unit Escort Service that had accompanied Rice's body home from the war, phoned his superiors in Oakland, California. They, in turn, brought the matter to the attention of the Army Quartermaster Corps in Washington, D.C. Army officials in the nation's capital responded by offering to transport Sergeant Rice's remains to the national cemetery of Evelyn Rice's choice. She selected nearby Fort Leavenworth, Kansas, and the army arranged to have the casket picked up on the morning of August $30{ }^{7}$

Word of the incident spread quickly. Neil McCluen, who had commanded the American Legion Honor Guard present at the burial, notified the Sioux City Journal, which ran an account of the incident and sent it out over the wire service. Sioux City veterans groups, labor organizations, and state politicians responded to the story by issuing strong condemnations of Memorial Park's burial policies. Laurens C. Shull of Sioux City's Veterans of Foreign Wars (VFW) Post 580 telegrammed VFW state headquarters in Des Moines, requesting it to take legal action against the cemetery, while Sioux City's American Legion Post 64 offered to pay for a burial lot in the city-owned Logan Park cemetery. Voicing the anger and embarrassment of many of his constituents, Republican Congressman Charles B. Hoeven of nearby Alton, Iowa, responded to a radio commentator's query as to whether all of Sioux City's people bore racial prejudices. Hoping to restore the city's good name, Hoeven argued that the citizens of western Iowa were "considerate folks and good Americans. Our intention always is to afford proper and honorable burial to every veteran regardless of race, creed, or color. ${ }^{18}$

Many of the local protests came from labor organizations. The Sioux City metropolitan council of the United Packinghouse Workers (representing Sioux City's largest industry)

7. Major General Harry H. Vaughn, military aide to the president, to Major General Herman Feldman, Quartermaster General, 9/11/1951; Memorandum for Major General Vaughn, 8/31/1951; Feldman to Vaughn, 8/31/1951, all in folder 471-B, Soldiers' Bodies, Sgt. John R. Rice, Official File, Truman Papers.

8. Sioux City Journal, 8/30 and 8/31/1951. 
adopted a resolution urging action to prohibit Memorial Park from displaying the American flag on "such an un-American piece of land," while officers of the Sioux City Trades and Labor Assembly condemned Memorial Park's burial policy as "unAmerican and contrary to the democratic principles of this great nation." A committee of Sioux City public school teachers declared its opposition to the cemetery's racial bigotry and demanded the abolition of its "obnoxious and discriminatory" burial clause. Local American Federation of Labor president Donald Thompson commented that "if we are willing to accept the services of a citizen in defense of democracy on a worldwide level and if he is ready to make the supreme sacrifice, we should be willing to let him join us in a last resting place regardless of race, creed, color, or ancestry." In a show of solidarity among racial minority groups, David Singer, the state director of the National Association for the Advancement of Colored People, called the incident "a slap in the face for our statesmen who are trying to sell democracy to the world. Can you picture the grin on Stalin's face as he reads the headlines in the American newspapers?" ${ }^{\prime 9}$

Within days, newspapers and magazines from around the country carried accounts of the story-the vast majority expressing outrage at the way a decorated soldier had been treated. Organizations ranging from the Association of American Indian Affairs and the Veterans of Foreign Wars (VFW) to the National Association for the Advancement of Colored People (NAACP) and the American Federation of Labor (AFL) issued written protests and adopted resolutions demanding that Memorial Park officials reconsider and reverse their decision. Oliver LaFarge, a spokesman for the Association on American Indian Affairs, summed up his organization's assessment of the incident as follows: "This is horrible. The manifestation of such an inhuman and anti-American attitude brings disgrace upon our country." Cards, letters, and phone calls from well-wishers around the country, meanwhile, indicated broad support and sympathy for the Rice family. On August 30, for example, Dr. Maurice Gershman and Lillian Margulies, officials connected with B'nai B'rith,

9. Ibid.; Hewitt, "The Indian Who Never Got Home," 14. 
the New York-based Jewish fraternal organization, sent two savings bonds for the Rice children with the hope "that others will do the same." The same day, members of the Vermontbased Barre Guild and Artisans in Stone offered to create and erect a granite memorial to Sergeant Rice. ${ }^{10}$

Under mounting pressure from local businessmen and citizens of Sioux City, as well as from citizens and organizations from across the country, local officials maneuvered to diffuse the firestorm as quickly as possible. In the afternoon of August 29, 1951, Clem Evans, who was serving as acting Sioux City mayor while Mayor Dan J. Conley was vacationing, met with several civic and political leaders, including William A. Shuminsky, commander-elect of Sioux City's Monahan American Legion Post, Sioux City Solicitor George Davis, Sioux City corporate counsel M. E. Rowlings, Memorial Park's J. M. Gunnell, and several prominent Sioux City businessmen. After the meeting, Evans announced that Memorial Park would send letters to all of its plot owners and stockowners, urging them to support removal of the clause. Evans added that he would deliver an apology to the widow. The next day the city council passed a resolution expressing regret and offering any burial lot in city cemeteries for free. ${ }^{11}$

Memorial Park officials launched their own efforts at damage control. After notifying Evelyn Rice of their decision not to bury her husband, cemetery officials offered to refund her money. When she refused to accept their offer, they suggested that if she -or Lieutenant Edward R. Krischel, the army bugler assigned to the burial detail-were willing to sign an affidavit certifying that Sergeant Rice was Caucasian, they would go ahead and bury him. Again she refused. Of paramount concern to cemetery offi-

10. Sioux City Journal, 8/31/1951; Sioux City History, Notable People, Sergeant John R. Rice, www.siouxcityhistory.org/people/more.php?id=3_0_2_0_M; "Taps for an Indian," Newsweek, 9/10/1951, 25; "Soldier's Burial," Time, 9/10 1951, 26; Memorandum for General Harry H. Vaughn regarding savings bonds from Gershman and Margulies, 9/10/1951, Official File, Truman Papers; Telegram to President Harry S. Truman from the Barre Guild and Artisans in Stone, 8/30/1951, ibid.; William Henry Deacy, executive director, American Institute of Commemorative Art, to Harry S. Truman, 9/12/1951, ibid.; Major General Harry H. Vaughn to William Henry Deacy, ibid.

11. "The Truth about the Sergeant Rice Incident." 
cials was their fear that allowing John Rice's burial at the cemetery could lead customers who had agreed to purchase lots in Memorial Park or who already had loved ones buried in the cemetery to sue for breach of contract. ${ }^{12}$

In the nation's capital, meanwhile, word of the incident reached the White House. On the morning of August 29, Major General Harry H. Vaughn, one of Truman's aides, brought the incident to the president's attention. How Vaughn found out about it is unclear, but it is possible that the Quartermaster Corps had alerted him the previous evening. President Truman, in characteristic "Truman style," directed Vaughn to take immediate action to correct the matter. The general responded by dashing off telegrams to Clem Evans, the acting mayor of Sioux City, and to Evelyn Rice, informing them that Truman believed that "national appreciation of patriotic sacrifice should not be limited by race, color, or creed." The president, he said, was willing to issue an executive order to have Sergeant Rice buried in Arlington National Cemetery if the family desired. Although plans were already under way to inter Rice's remains at Fort Leavenworth, Evelyn Rice-aware that burial at Arlington would be a greater honor for her husband-decided to take the president up on his offer. ${ }^{13}$

Truman's action proved popular across the country. White House mail heavily supported his decision, and several Sioux City area radio stations broadcast sympathetic editorials. ${ }^{14}$ Truman received a warm letter from Mary McLeod Bethune, former head of the Division of Negro Affairs of the National Youth Administration and special assistant to the secretary of war during

12. Sioux City Journal, 8/29/1951; Ross, "The Indian Who Never Got Home," 7.

13. Major General Harry H. Vaughn to Major General Feldman, 9/11/1951, Official File, Truman Papers; Memorandum for Major General Vaughn, $8 / 31 / 1951$, ibid.; Telegram from Major General Harry Vaughn to the Mayor of Sioux City, 8/29/1951, ibid.; Telegram from Major General Vaughn to Evelyn Rice, 8/29/1951, ibid.; Telegram from Clem A. Evans, Acting Mayor of Sioux City to Major General Harry H. Vaughn, 8/30/1951. Truman's executive order was designed to expedite the burial and relieve the family of the bureaucratic burden of filing applications, etc. Sergeant Rice was entitled to be buried in Arlington National Cemetery by virtue of his service.

14. Sioux City Journal, 8/30/1951; Donald R. McCoy and Richard T. Ruetten, Quest and Response: Minority Rights and the Truman Administration (Lawrence, KS, 1973), 296. 
World War II. "We bless you for your stand for American justice and recognition, in the burial of Sergeant Rice," she wrote. "I just want to thank you for your courage, and for your heart's understanding of what is right and kind and appropriate. . . . Your stock with the masses has definitely gone up," she commented. "We are standing close beside you for 1952."

What followed was an unprecedented, high-profile community expression of honor and respect. On the morning of Sunday, September 2, 1951, almost a week after the incident at Memorial Park, Sergeant Rice's family and friends again set out to lay his body to rest. Military and public officials, as well as veterans organizations, scrambled to be a part of something that promised to rekindle the passion and patriotism of the World War II era. Master Sergeant John C. Boles, five officers from the army's Nebraska District, and General Guy N. Henninger, commander of the Nebraska National Guard, representing Nebraska Governor Val Peterson, all escorted Sergeant Rice's body from Winnebago to South Sioux City, Nebraska. American Legion members selected from Alvin Londrosh Post 174 and Lamere Greencrow Post 363, both of Winnebago, went ahead and waited on the Iowa side of the bridge in Sioux City that linked the state with Nebraska. Shortly after 10:00 a.m., the funeral procession arrived in Sioux City. A police escort of four motorcycles and one squad car containing various community leaders as well as the 20-man escort of Legionnaires accompanied the mourners on a solemn drive to the Milwaukee Road train station, where an additional 1,000 people had gathered to pay tribute to Sergeant Rice. Once at the train station, the flag-draped casket was borne through two ranks of the escort, which stood with arms presented. Rev. Daniel Madlan, pastor of St. Augustine Catholic Church at Winnebago, said a brief prayer, and pallbearers placed the body aboard the train for transport to Washington, D.C. Accompanying the body east were John Rice's mother, sister, and two military escorts. Evelyn Rice and other family members flew to Washington, D.C., via military aircraft two days later. ${ }^{16}$

15. Mary McLeod Bethune to Harry S. Truman, 9/8/1951, Official File, Truman Papers.

16. Sioux City Journal, 9/2/1951, 9/3/1951. 
On the morning of September 5, 1951, a black caisson drawn by six gray horses bore Sergeant Rice's body, encased in a flagcovered coffin, from the chapel at Fort Myer, Virginia, to the gravesite in section 34 of Arlington National Cemetery (itself segregated until 1947). The site of the burial was but a short distance from the graves of General John J. Pershing, commander of the American Expeditionary Forces during World War I (and a longtime admirer of Indian soldiers), and General Walton Walker, former commander of the Eighth Army in Korea. Present at the ceremony were numerous dignitaries, including Senators Guy M. Gillette (D) and Bourke B. Hickenlooper (R) of Iowa, Senator Hugh Butler (R) of Nebraska, Secretary of the Interior Oscar L. Chapman, and Commissioner of Indian Affairs Dillon S. Myer. Major Charles B. Palmer (Sergeant Rice's former commander in Korea) was also in attendance. After a brief prayer service performed by Fort Myer chaplain John Forzell, the casket was lowered into the grave as the honor guard fired the traditional three volleys and the bugler sounded taps. Later that evening, the Rice family flew home, no doubt grateful that their loved one had received the honor he deserved - an honor bestowed in a fashion few Indians had ever received-and that the unpleasantness of the previous week-and-a-half was finally over. ${ }^{17}$

NONETHELESS, the discrimination John Rice had fallen victim to after having made the ultimate sacrifice for his country weighed heavily on Evelyn Rice in the days following his funeral. Compounding her anger and grief was the realization that Memorial Park cemetery continued to operate as it always had-seemingly unfazed by the bad publicity it had received in the weeks immediately following its refusal to bury Sergeant Rice. Cemetery officials characterized the public outcry over their burial policy as "mob hysteria," and produced a pamphlet that sought to justify their actions. The pamphlet, titled "The Truth about the Sergeant Rice Incident," argued that Evelyn Rice had had ten days to review the burial contract, "which was ample time to inform herself of its contents and restrictions." It

17. Sioux City Journal, 9/6/1951, 9/5/1951; Washington Post, 9/5/1951; Miscellaneous news clippings from the Philleo Nash Papers, Truman Library. 
also presented an "expert opinion" from Canadian archaeologist Dr. R. S. McNeish that American Indians were descended from "Wild Mongolian Nomads" who came to North America from Asia, proving that "the American Indian is not of Caucasian descent." Cemetery officials also noted that 90 percent of private cemeteries in the United States had racial restrictions, and that the practice of limiting burial to members of the Caucasian race was "almost as old as the cemetery business" itself. ${ }^{18}$

From Evelyn Rice's perspective, the cemetery's publication and distribution of the pamphlet was the last straw. On December 12, 1951, she brought suit against Memorial Park cemetery for its "willful and malicious" behavior (refusing to bury her husband and circulating the pamphlet), which had caused her "great mental distress, humiliation, emotional fatigue, and nervous exhaustion." Her attorneys (Neil R. McCluen of Winnebago, Nebraska, and Lowell Kindig and Robert Beebe of Sioux City) argued along two separate tracks. First, they contended that Memorial Park cemetery had humiliated Evelyn Rice and committed a breach of contract by refusing to bury her husband. The second track was a constitutional argument centered on the cemetery's restrictive burial clause (or restrictive covenant). Rice's attorneys based their arguments for Memorial Park's breach of contract on an unusual interpretation of the burial clause. From their perspective, since Evelyn Rice was Caucasian and the person who had signed the contract, she was the owner of the lots and ought to be able to bury her husband in one of them. In a secondary argument (that must have angered John Rice's Winnebago parents and family), the attorneys argued that since John Rice was 11/16 Winnebago and 5/16 Caucasian, he should have been allowed burial as he was Caucasian! Should the court not support the breach of contract arguments, Rice's attorneys would then focus on the constitutional issue- that the contract itself was unconstitutional and that the cemetery's policy of restricting burial to "members of the Caucasian race" violated the Fourteenth Amendment to the U.S. Constitution, as well as Article One, sections one and six, of the Iowa Constitution. ${ }^{19}$

18. "The Truth about the Sergeant Rice Incident."

19. Rice v. Sioux City Memorial Park Cemetery, Inc., et al., 102 F. Supp 658 (U.S. District Court for the Northern District of Iowa, Western Division, 2/4/1952); 
Memorial Park's defense strategy was simple: cemetery officials had negotiated hundreds of burial contracts over the years-all with the race restrictive clause. The contract was clearly written, and Evelyn Rice had signed it voluntarily. Even if cemetery officials had wanted to bury John Rice, they would have been legally obligated to obtain the permission of all living lot owners and surviving family members of people already buried (which was impractical), or face numerous potential breach of contract suits that would have driven them out of business. ${ }^{20}$

After hearing arguments later that year, the Woodbury County District Court dismissed the case in December 1952. Judge Ralph C. Prichard cited Memorial Park's right to "stand upon the terms of its contract," ruling that the cemetery was not in breach since the restrictive burial clause referred to the person to be buried rather than the owner of the lot. Second, the court ruled that John Rice was not Caucasian; Memorial Park officials were within their rights, therefore, to enforce the terms of the contract. The judge then moved to address the key constitutional and civil rights questions raised in the case. Was the restrictive covenant a violation of Evelyn Rice's rights under the Fourteenth Amendment? Did the Fourteenth Amendment forbid the state of Iowa from enforcing a contract if it contained such a covenant? If Iowa courts allowed the cemetery to enforce the contract, were they not providing de facto recognition and legitimacy for the cemetery's discriminatory burial clause? In the

Rice v. Sioux City Memorial Park Cemetery, Inc. et al., 245 Iowa 147 (Supreme Court of Iowa, 9/22/1953); Rice v. Sioux City Memorial Park Cemetery, Inc., et al., 349 U.S. 70 (U.S. Supreme Court, 1955).

20. Ibid.

21. Three days into the trial, Memorial Park's legal team requested that the case be removed to the U.S. district court in Sioux City amid questions over whether or not Woodbury County District Court had jurisdiction in the matter. Two months later (on February 4, 1952), U.S. District Court Judge Henry N. Graven sent the case back to Woodbury County. Among the reasons Judge Graven cited in his decision to remand was that since the cemetery was privately owned, "neither the State of Iowa nor any of its agencies" had any connection with the ownership or operation of the cemetery or "with the transaction in question." Graven also expressed "considerable doubt" as to whether there was an "independent claim or cause of action which presented a controversy arising under the Constitution of the United States." 
landmark Shelley v. Kraemer case (1948), the U.S. Supreme Court had ruled that private agreements with restrictive covenants did not violate the Fourteenth Amendment, but it was a violation of the Equal Protection Clause of the Fourteenth Amendment for state courts to enforce them. Basing their argument on the Shelley v. Kraemer precedent, Evelyn Rice's attorneys maintained that if the court ruled that the burial contract was valid, it was in fact sanctioning a violation of the Fourteenth Amendment's Equal Protection Clause. ${ }^{22}$

Judge Prichard did not buy the argument. He insisted that the Shelley $v$. Kraemer precedent did not apply to Rice v. Sioux City Memorial Park Cemetery. Focusing particular attention on the meaning of "state court enforcement," the judge held that in Shelley $v$. Kraemer, the U.S. Supreme Court had barred state courts only from providing direct aid (by granting injunctions, specific performance, and other active aids) to the enforcement of race restrictive covenants. Issuing a court ruling in support of a contract with a restrictive covenant, in Judge Prichard's opinion, did not fall under the umbrella of providing direct aid. Recognizing that the contract between Evelyn Rice and Memorial Park cemetery was a private agreement, the judge declared that the state of Iowa was simply a neutral party in the matter-certainly not exerting direct aid to enforce a discriminatory act. ${ }^{23}$

What Evelyn Rice was requesting, Judge Prichard extrapolated, was for the state to go beyond Shelley $v$. Kraemer to declare void any private contract with a restrictive covenant, to alter a contract that she voluntarily entered into with another private party, to punish Memorial Park for enforcing the contract, and to bar the recognition of restrictive clauses in contracts between private parties even though no active state aid was given in their

22. Rice v. Sioux City Memorial Park Cemetery, Inc., et al., 102 F. Supp 658 (U.S. District Court for the Northern District of Iowa, Western Division, 2/4/1952); Rice v. Sioux City Memorial Park Cemetery, Inc. et al., 245 Iowa 147 (Supreme Court of Iowa, 9/22/1953); Rice v. Sioux City Memorial Park Cemetery, Inc., et al., 349 U.S. 70 (U.S. Supreme Court, 1955).

23. If, on the other hand, Evelyn Rice had directed family or friends to lower her husband's body into the ground in violation of her agreement, the state would have had to deny Memorial Park assistance in restraining her, nor could it have entertained an action for damages against her for violating the agreement. 
enforcement. While sympathetic to Evelyn Rice's predicament, Judge Prichard was unwilling to expand the meaning and scope (as he understood it at least) of Shelley v. Kraemer. On appeal, the Iowa Supreme Court, in a unanimous decision issued on September 22, 1953, affirmed the lower court's ruling in toto, with Justice Robert L. Larson declaring that the "moral ends" of the plaintiff did not "justify the means she sought to obtain them."

Despite these legal setbacks, Evelyn Rice pressed on. In mid-November 1954 (roughly three years after her husband's burial) she had cause for hope when the U.S. Supreme Court heard arguments in the case. A divided court affirmed the Iowa Supreme Court decision but issued a writ of certiorari, indicating that four justices were interested in exploring Iowa's willingness to enforce the "restrictive [burial] covenant." In the opinion of these justices, the role of Iowa state officials in the John Rice incident rendered the case "special and important."

Evelyn's hope proved short lived, however. Five months later (on May 9, 1955), the U.S. Supreme Court (although still divided 5-3 on the issue) dismissed the writ of certiorari it had issued earlier, noting that it had been "improvidently granted." According to Justice Felix Frankfurter, key to the court's opinion was the Iowa state legislature's enactment on April 21, 1953, of "corrective legislation" that made it unlawful for any organization (except churches, established fraternal societies, or incorporated cities, towns, or other political subdivisions of the state of Iowa) to deny burial "solely because of the race or color of such deceased person." In addition, the new law voided all existing contracts or regulations that restricted burial based on race or color. Violations were punishable by a fine of 25 to 100 dollars per occurrence. "Had the statute been properly brought to our attention and the case thereby brought into the proper focus," Justice Frankfurter scolded, "the case would have assumed such

24. Rice v. Sioux City Memorial Park Cemetery, Inc., et al., 102 F. Supp 658 (U.S. District Court for the Northern District of Iowa, Western Division, 2/4/1952); Rice v. Sioux City Memorial Park Cemetery, Inc. et al., 245 Iowa 147 (Supreme Court of Iowa, 9/22/1953); Rice v. Sioux City Memorial Park Cemetery, Inc., et al., 349 U.S. 70 (U.S. Supreme Court, 1955).

25. Rice v. Sioux City Memorial Park Cemetery, Inc., et al., 349 U.S. 70 (U.S. Supreme Court, 1955). 
an isolated significance that it would hardly have been brought here in the first instance. ${ }^{26}$

Dissenting from the decision to dismiss the case were Justices Hugo Black, Earl Warren, and William O. Douglas. According to Justice Black, serious questions arising from Rice v. Sioux City Memorial Park concerning the equal protection of the laws guaranteed by the Fourteenth Amendment remained undecided. The court dismissed the case, he argued, because the Iowa legislature had passed new legislation that protected every person in Iowa except Evelyn Rice, "the one who has already filed a suit to prosecute claims like this." The new cemetery law, he continued, "leaves everyone in Iowa free to vindicate this kind of right except the petitioner." This obvious injustice, Black concluded, "raised a new question of equal protection of the laws equally as grave as those which prompted us to take this case originally."

Although the U.S. Supreme Court granted a petition for rehearing, Evelyn Rice was fed up after nearly three years of court battles, and no additional legal efforts were mounted in her behalf. While disappointed that both state and federal courts had ruled against her petitions, Evelyn Rice may have drawn some comfort from the realization that her husband's death helped bring about the enactment of a state law that promised to prevent the type of injustice and dishonor that she, her family, and the entire Winnebago Nation had endured since August 1951. Burial ground segregation, characterized in a 1955 California lawsuit as a "particularly stupid form of human arrogance and

26. Ibid. The bill (Senate File 71), "An Act relating to the operation of cemeteries in the state of Iowa, and funds for the perpetual care and maintenance thereof, and the sale of burial space therein, and providing penalties for the violation thereof" was introduced on January 22, 1953. The Senate passed it on February 16, and the House passed it on April 15. The vote was unanimous in both chambers. 1953 Iowa Senate Journal, 69, 314; 1953 Iowa House Journal, 1244-45. To view the bill, see 1953 Laws of Iowa, chap. 84, 161-64 or the DocSTAR Web site at http:/ /docstar.legis.state.ia.us/dswv. Incidentally, the provision striking down existing burial contracts with the race-restrictive covenant appears to violate Article 1, section 10 of the U.S. Constitution, which prohibits states from passing laws impairing the obligation of contracts.

27. Rice v. Sioux City Memorial Park Cemetery, Inc., et al., 349 U.S. 70 (U.S. Supreme Court, 1955); David Fellman, "Constitutional Law in 1954-1955," American Political Science Review 50 (1956), 93-95. 
intolerance," would no longer slight Iowa's racial minorities. ${ }^{28}$ The John Rice incident, therefore, played a role in transforming the Iowa Code into a system of laws that ensured justice and fair treatment for all of its citizens.

\section{ANTI-INDIAN PREJUDICE AND RACISM in Sioux City} and throughout much of the American West had never been as intense or imbedded as that directed against African Americans in southern states with long traditions of institutionalized slavery followed by legal segregation. But it existed and found expression in similar ways. Some western state and local governments denied welfare or general assistance to Indians because of their status as "wards" of the federal government. Restrictive covenants in housing sometimes prevented Indians from living in certain neighborhoods. Arizona and New Mexico did not allow Indians to vote in state elections until 1948. Prejudice was often manifested in bans against American Indians purchasing liquor or patronizing some bars and saloons and in a variety of less formal social and economic discriminations. ${ }^{29}$

Evelyn Rice noted to reporters that even before her own marriage she had seen discrimination after her sister married John Rice's brother. And she experienced it personally in Sioux City, explaining that the more equal treatment the couple found in other cities around the country where John Rice had been stationed made her especially aware of it. Rev. Harvey Nelson, president of Sioux City's Ministerial Association, representing 70 pastors of a number of denominations, drew attention to the discrimination as well. In a statement issued in response to the Sergeant Rice incident, he said, "We know that racial prejudice is prevalent and disastrous. This situation is an example of what absurd extremes it will take and to what lengths it will go." ${ }^{30}$

At the national level, the World War II experience had proved a springboard for civil rights movements among African Ameri-

28. Fellman, "Constitutional Law in 1954-1955," 95n (re: Long v. Mountain View Cemetery Association [1955]).

29. Ross, "The Indian Who Never Got Home," 17; Theodore Haas, "Restrictive Covenants and the Indians," The American Indian 4 (1948), 11-15.

30. Sioux City Journal, 8/30/1951. 
cans, Native Americans, and other racial minorities. Military service sometimes threw together people from different parts of the country with widely divergent backgrounds and racial attitudes. While African Americans served in segregated units and occasionally encountered white soldiers or civilians who abused them, American Indians served in integrated units and often found military life an assimilating experience. Wartime camaraderie often overcame existing prejudices and broke down racial barriers. Back home, the nationalism generated by World War II led more Americans to become more tolerant of ethnic and racial minorities, and the military effort became a cause that transcended traditional divisions. The war gave those accorded only marginal status an opportunity to "prove" themselves equal. Patriotism, after all, demanded that anyone who participated in the war should receive honor and respect. ${ }^{31}$

For a large, industrial society mobilizing to battle against fascism and totalitarianism, it quickly became obvious that the social complications of racism impeded the smooth prosecution of the war. Moreover, racism seemed outdated and simply wrong in the broader context of a nation of diverse people unified in a common cause. A segregated American military fighting a crusade against fascist totalitarianism and its ideology of racial inequality invited comparison to the embarrassing contradiction in America's historical treatment of its own racial minorities. The war also provided an opportunity to link war goals of defending democracy internationally to movements for expanding democracy and civil rights at home. African Americans fought for "Double V"-victory both abroad and at home. Minority veterans came out of the war with the conviction that they

31. Richard M. Dalfiume, "The 'Forgotten Years' of the Negro Revolution," Journal of American History 55 (1968), 90-91, 103-4; Neil A.Wynn, The AfroAmerican and the Second World War (New York, 1975), 99; McCoy and Ruetten, Quest and Response, 11-12; A. Russell Buchanan, Black Americans in World War II (Santa Barbara, CA, 1977), 131; Richard M. Dalfiume, Desegregation of the Armed Forces: Fighting on Two Fronts, 1939-1953 (Columbia, MO, 1969), 132; Bernstein, American Indians and World War II, 24-44, 58, 87, 110, 114; David G. McCullough, Truman (New York, 1992), 589; Tom Holm, "Fighting a White Man's War: The Extent and Legacy of American Indian Participation in World War II," Journal of Ethnic Studies 9 (1981), 74; Jere Bishop Franco, Crossing the Pond: The Native American Effort in World War II (Denton, TX, 1999), 156-59. 
should not have to return to a status of anything less than full inclusion and equality. ${ }^{32}$

The cause of civil rights in post-World War II America was also aided by the common belief that racial discrimination undermined America's position in the Cold War. The two Cold War superpowers competed for the support of developing nations, and the vast majority of the people in those countries were people of color. How could the United States convince them to take its side in the Cold War when the blemishes in its own record of civil rights for racial minorities were so obvious? The symbiotic relationship between the federal government's Cold War and civil rights policies became clear in the report of Truman's 1947 Committee on Civil Rights. The report, titled "To Secure These Rights," argued that there were three reasons civil rights abuses required the government's attention: a moral reason-discrimination was morally wrong; an economic reasondiscrimination was bad for the economy; and an international reason-discrimination undermined U.S. foreign relations because the Soviet Union seized on reports of discrimination and race-motivated violence to damage American credibility in the Third World. ${ }^{33}$

Dramatic episodes such as the John Rice incident, moreover, gave the Soviets ammunition to counter American claims of Soviet human rights abuses being committed behind the Iron Curtain. In January 1951, for example, Tass, the official Soviet news agency, described American culture as "decadent" and "depraved" and cited as evidence the "fact" that slavery, while nominally abolished, actually continued to exist. Just two months after the John Rice incident, Soviet Foreign Minister Andrei Vishinski, at a session of the United Nations General Assembly, accused the United States of violating human rights by lynching blacks and referred specifically to the killing of an African American prisoner in Florida by the sheriff who was guarding him. The author of an article in The Nation in the fall of 1959 summed up a key problem in American foreign policy

32. Dalfiume, "The 'Forgotten Years' of the Negro Revolution," 93-97; Buchanan, Black Americans in World War II, 113-15.

33. Mary L. Dudziak, Cold War Civil Rights: Race and the Image of American Democracy (Princeton, NJ, 2000), 79-82. 
with the assessment that "Jim Crow at home seems to have bankrupted our diplomatic resources" abroad. ${ }^{34}$

Whether the Soviet Union used the John Rice incident for propaganda is unknown, but it certainly could have..$^{35}$ David Sanger, chair of the Iowa branch of the NAACP, described the Rice matter as a "slap in the face for our statesmen who are trying to sell democracy to the world. Can you picture the grin on Stalin's face," Sanger lamented, "as he read the headlines in the American newspapers?" Nebraska Governor Val Peterson echoed such concerns. "You couldn't manufacture better ammunition for the communists if you sat up all night and tried," Peterson declared shortly after the John Rice incident. "It is hard to understand how some Americans want to be Stalin's unwitting assistants." ${ }^{36}$

The Truman administration was certainly sensitive to the effect that episodes of racial discrimination had on America's position in the Cold War. According to historian Mary L. Dudziak, President Truman repeatedly emphasized the importance of civil rights for U.S. foreign policy, and he promoted "human rights with the goal of preserving world peace." If America was to be victorious in its crucial battle against the Soviet Union for global influence, Truman argued in February 1948, the United States had to "correct the remaining imperfections in [its] practice of democracy. ${ }^{\prime \prime 7}$ By responding as he did to the Sergeant Rice incident, Truman may have been trying to "correct a remaining imperfection" so as to disarm (or at least blunt) an embarrassing Soviet propaganda weapon-one aimed at capitalizing on the scandalous treatment accorded an American war hero who had given his life fighting for democracy and freedom and against the expansion of communist tyranny in South Korea.

34. Charles Allan Baretski, "Cabbages or Artichokes," School and Society, 12/8/1951, 353-57; William A. Rutherford, "Jim Crow: A Problem in Diplomacy," The Nation, 11/8/1951, 428-29.

35. Anecdotal evidence suggests that the Soviets did indeed make use of the John Rice incident. At a reading of an earlier version of this paper at a history conference in 1998, a gentleman in the audience commented that he had heard about the John Rice matter while stationed in West Berlin. He stated that the East Berlin radio station was making much ado about the story!

36. Sioux City Journal, 8/30/1951; Hewitt, "The Indian Who Never Got Home," 18.

37. Dudziak, Cold War Civil Rights, 82, 87. 
PRESIDENT TRUMAN was, in fact, an unlikely advocate in the cause of civil rights. He had grown up in a time and in a part of Missouri where racism and social prejudice were imbedded in local white culture, and he never outgrew the racial biases of his youth. But, guided by his sense of nationalism, he did move toward a more egalitarian position throughout his life. By the time he entered politics in the 1920s, he had developed a strong belief in the U.S. Constitution as a solid anchor, a source and protector of liberties and freedoms. In a 1940 local campaign speech that was surprisingly bold for the time and place, he expressed belief in "the brotherhood of all men before the law," arguing that "if any class or race can be permanently set apart from, or pushed down below the rest in political and civil rights, so may any other class or race." The federal government, according to Truman, had the responsibility to guarantee equal treatment before the law, equality of opportunity, and civil rights for all Americans. ${ }^{38}$

Truman's own military experience contributed to changes in his racial attitudes. A veteran of World War I, he appreciated the sacrifice that each soldier and sailor had made in defense of the U.S. Constitution. During World War II and the few years thereafter, newspapers carried stories on vigilante enforcement of traditional racial codes. Thugs attacked minority soldiers stationed in southern states and sometimes even went after minority veterans returning from the war. In 1946 Truman learned that the Ku Klux Klan had stepped up its level of violence, with minority soldiers as occasional victims. Truman was appalled and pursued prosecution whenever possible. ${ }^{39}$

The evolution of Truman's views on race and civil rights paralleled that of other liberal Americans in the post-World War II era. Increasingly they saw civil rights as both a moral and a legal imperative. But that change in thinking far outpaced the average American voter. In acting, Truman took a sizable political

38. Harry S. Truman, "Statement by the President," Public Papers of Harry Truman, 414; McCoy and Ruetten, Quest and Response, vii; Alonzo L. Hamby, Beyond the New Deal: Harry S. Truman and American Liberalism (New York, 1973), 61, 65; Michael R. Gardner, Harry Truman and Civil Rights: Moral Courage and Political Risks (Carbondale, IL, 2002), 6.

39. Gardner, Harry Truman and Civil Rights, 6; McCullough, Truman, 589. 
risk. He rated low in public opinion polls, and Americans overwhelmingly opposed civil rights legislation. No groundswell of support from a popular civil rights movement helped him as it would later presidents. He created the President's Committee on Civil Rights in 1946 based on little more than personal conviction. Several times he tried to push legislation through Congress to implement the committee's recommendations, but he was limited by political realities. In most cases he backed off his initiatives in the face of southern opposition within his own party. ${ }^{40}$

In civil rights for African Americans, Truman's actions conformed generally with the goals of the emerging civil rights movement; in Indian policy, however, Truman inadvertently joined ranks with a movement that was trying to reverse the "Indian New Deal" of Franklin Roosevelt. Roosevelt had appointed to key policy-making positions people who were committed to a radically new vision of Indians and their place in America. His commissioner of Indian Affairs, John Collier, pushed the Indian Reorganization Act (IRA) through Congress in 1934. Congress gave Collier only a portion of what he wanted, but he worked tirelessly to end longstanding federal efforts to forcibly assimilate Indians, end their special status as "wards" of the federal government, and move toward a policy based on cultural pluralism - an acceptance of Indian sovereignty, a revitalization of tribalism, a reconstitution of Indian self-government, and a preservation of Indian cultures where desired. ${ }^{41}$

Collier may have crippled forced assimilation, but he had not killed it. Opponents challenged Collier's Indian New Deal almost from the start. Cultural pluralism, apparently, had never established deep roots. The last real champion of the IRA in the House, Edgar Howard (D-NE), was defeated for reelection in 1934. Few supporters remained in Congress by the 1940 s, and

40. McCullough, Truman, 588; Hamby, Beyond the New Deal, 188-89, 214, 23233, 243, 291; Gardner, Harry Truman and Civil Rights, 12-15.

41. See Lawrence C. Kelly, The Assault on Assimilation: John Collier and the Origins of Indian Policy Reform (Albuquerque, NM, 1983); Kenneth R. Philp, John Collier's Crusade for Indian Reform, 1920-1954 (Tucson, AZ, 1977); Graham D. Taylor, The New Deal and American Indian Tribalism: The Administration of the Indian Reorganization Act, 1934-1945 (Lincoln, NE, 1980); and Lawrence C. Kelly, "The Indian Reorganization Act: The Dream and the Reality," Pacific Historical Review 44 (1975), 291-99. 
criticism of the Indian New Deal from within and outside of Congress forced Collier into a defensive posture by the World War II years. Uncertainty about the Indian New Deal and a consensus for reducing the government's role in Indian affairs was growing. Even former IRA supporters such as Oliver LaFarge, head of the influential, mostly white, Indian affairs advocacy group, the Association on Indian Affairs; had grown frustrated with the failure of the IRA to reduce the control exercised by the Bureau of Indian Affairs (BIA) over Indians and favored Collier's plan for federal withdrawal. ${ }^{42}$

Indian opinion was mixed as well. World War II nationalism had created an atmosphere in which most Americans (even some Indians) thought that assimilation in some form was inevitable. Many Indian veterans of Sergeant Rice's generation had grown accustomed to the more equal treatment and status they had enjoyed in the military and sought the removal of any barriers to full individual rights under U.S. citizenship, such as bans on alcohol sales in some areas. But while most Indians wanted to retain tribal rights and group identity, most non-Indians did not include those traditions in what they viewed as a reward for Indian participation in war. ${ }^{43}$

Collier's opponents came from both parties, but they were all conservative critics of Roosevelt's New Deal from western states. Some from both parties had ties to non-Indian economic interests who saw individualistic assimilation as the best means to gain access to resources on Indian lands unavailable to them under restricted trust status. In the late 1930s and 1940s, critics introduced bills to repeal the IRA, to strip the BIA of authority to manage tribal funds, to remove trust restrictions on allotments, and to allow states to extend their penal laws over reservations. They did not yet have the votes for any dramatic policy reversal, but they eventually succeeded in stalling the Indian New Deal by cutting its funding levels, blocking any further legislation, and insisting that the BIA begin to plan for federal withdrawal from Indian affairs. ${ }^{44}$

42. Bernstein, American Indians and World War II, 110, 164, 170.

43. Ibid., 133, 136-41.

44. John S. Painter, "Congressional Conservatism and Federal Indian Policy, 1928-1950" (paper presented at the annual meeting of the Organization of 
In response, Collier came up with a long-term plan to get the government out of Indian affairs. But his version of assimilation included assimilating Indians as tribes rather than as individuals in order to protect tribal autonomy and self-government. His plan called for rehabilitating reservations at federal expense and gradually transferring the government's role to tribal councils. The BIA generated specific rehabilitation plans for several reservations, but they collected dust. Congress was unwilling to spend the necessary money, and the plans languished without support. The beleaguered commissioner finally resigned in frustration in 1945, but he remained confident that what he had left behind would survive the difficult political climate and represent a lasting legacy. ${ }^{45}$

Collier's assimilationist opponents believed that Indian sovereignty could not coexist with American sovereignty and that individual rights based on U.S. citizenship should displace tribal rights based on membership in any Indian group. They looked condescendingly at American Indian cultures as "museum pieces" and criticized Collier and the IRA for taking Indians "back to the blanket." ${ }^{\prime 46}$

Through the 1930s and 1940s, assimilationists added their voices to the conservative critique of New Deal liberalism, deficit spending, and the explosion of federal bureaucracies. Conservative assimilationists favored a libertarian economic individualism and opposed government regulation of the economy and most spending on social programs. They portrayed the BIA as another unnecessary government bureaucracy, arguing that Indian trust land restrictions and tribal economic development

American Historians, Detroit, Michigan, 4/2/1981), 3, 10-15; Frederick J. Stefon, "The Irony of Termination: 1943-1958," The Indian Historian 11 (1978), 4-5; Larry W. Burt, Tribalism in Crisis: Federal Indian Policy, 1953-1961 (Albuquerque, NM, 1982), 4-5.

45. U.S. Congress, Senate, Survey of the Conditions among the Indians of the United States, Partial Report Number 310, 78th Cong., 2nd Sess., 1943; Congressional Record, 78th Cong., 1st sess., 1943, 4020, 5597, 7168; S. Lyman Tyler, Indian Affairs: A Work Paper on Termination with an Attempt to Show Its Antecedents (Provo, UT, 1964), 27, 29-30; Larry J. Hasse, "Termination and Assimilation: Federal Indian Policy, 1943-1961" (Ph.D. diss., Washington State University, 1974), 42-54; John Collier, From Every Zenith: A Memoir and Some Essays on Life and Thought (Denver, 1963).

46. Burt, Tribalism in Crisis, 4-5, 19-20. 
violated the free marketplace based on individual property rights and private enterprise. The postwar economic boom, recent technological innovation, and the explosion in the consumer culture all encouraged a common assumption that everyone wanted to live like modern, white Americans. A few went so far as to combine an intense anticommunism with their opposition to the New Deal, and to compare Indian communal traditions and the bureaucracy of government programs on reservations to communist totalitarianism. ${ }^{47}$

What emerged was a "liberation" view of federal Indian policy. Paternalistic government programs of sending bureaucrats to reservations to teach and enforce assimilation had failed. Only a sink-or-swim approach to integrating Indians as individuals rather than as tribes would succeed. Terminationist later became the label for this position because advocates wanted to terminate tribal status. They called for an end to the reservation system and a withdrawal of the government's role in Indian affairs by eliminating the IRA, the BIA, and separate tribal sovereignty. Indians needed to be freed from government paternalism and from the restrictions of separate Indian culture and status, terminationists argued, because these things only prevented American Indians from integrating into American life and competing as individuals in an open economy and society. ${ }^{48}$

The departure of the small group of committed cultural pluralists within the Department of the Interior signaled a fundamental shift in the administration of Indian Affairs. The administration's newcomers favored Collier's plan for federal withdrawal, but they were less forceful in promoting the cultural preservation and separate tribal sovereignty dimensions of the Indian New Deal. ${ }^{49}$

47. Ibid.

48. Ibid. For a summary of the "liberation" view of Indian policy, see O. K. Armstrong, "Set the American Indian Free," Reader's Digest, August 1945, 4752. For rebuttals from the rehabilitation/IRA point of view, see Haven Emerson, "Freedom or Exploitation! Is Mr. O. K. Armstrong's Recent Solution of the American Indian Problem Sound?" American Indian 2 (Fall 1945), 2-7; and Randolph C. Downes, "The American Indian Can Be Free," ibid., 8-11.

49. John Collier, "Beleaguered Indian," The Nation, 9/17/1949, 276-78; idem, "The Indian Bureau and Self-Government: A Reply to John F. Embryo," Human Organization 8 (Summer 1949), 22-26; Felix S. Cohen, "Breaking Faith with Our 
The 1946 off-term elections swept Republicans into control of Congress for the first time since 1930, and put assimilationists into their strongest position since the Indian New Deal. But the congressional terminationists failed to coordinate their piecemeal actions into a coherent movement. The Department of the Interior and some congressional Democrats opposed most individual tribal termination bills in committee actions, arguing that the tribes under consideration were not ready. With one exception, bills that got beyond committee action in the Eightieth Congress were minor, local matters that did little to affect overall policy. ${ }^{50}$

One reason for the terminationists' initial failure was that Indian affairs had become a low priority in national politics. Few members of congress, moreover, knew much about Indians or what they wanted. Tribes no longer presented military threats, and the nation had become a superpower with a global foreign policy and the world's leading economy. Congressional leadership had difficulty finding members of congress who were willing to serve on or chair the low-prestige, low-reward committees that dealt with Indian affairs. Indians had not yet developed their own organizations to effectively lobby politicians or public opinion. ${ }^{51}$ All this meant that considerations outside of Indian communities influenced politicians more than Indian voices in creating policy and that a small group of determined people could engineer major change in federal policy. John Collier had demonstrated that, and terminationists soon would do the same.

First Americans," Indian Truth 25 (March 1948), 1-8; idem, "The Civil Rights Report," Review of General Semantics 4 (1948), 161-67; idem, "Indian SelfGovernment," American Indian 5 (1949), 3-12; idem, "Our Country's Shame!" Progressive 13 (May 1949), 9-10; idem, "The Erosion of Indian Rights, 19501953: A Case Study in Bureaucracy," Yale Law Journal 62 (1953), 348-90; Harold L. Ickes, "On Frisking the Alaska Indians," New Republic, 5/9/1949, 19; idem, "Justice in a Deep Freeze," New Republic, 5/21/1951, 17; Kenneth R. Philp, Termination Revisited: American Indians on the Trail to Self-Determination, 19331953 (Lincoln, NE, 1999), 69-71, 76, 80-83.

50. 1947 Congressional Quarterly Almanac 3 (1948), 325-26, 493, 688-89; U.S. Congress, House, Committee on Public Lands, Subcommittee on Indian Affairs, Hearings on H.R. 2958, H.R. 2165, and H.R. 1113: Emancipation of Indians, 80th Cong., 1st sess, 1947.

51. The National Congress of American Indians, founded in 1944, was making impressive strides, but it did not become influential in federal Indian policy until its fight against termination in 1953. 
The only major piece of legislation affecting Indian policy in 1946 was one that all sides agreed upon. The Indian Claims Commission Act (ICC) created a special court to hear cases by tribes against the government for inadequate compensation in land settlements or failure to properly administer trust lands. Previously, each group first had to go through the cumbersome process of obtaining special enabling legislation from Congress to sue the government. Some supported the ICC for reasons of justice, efficiency, or the many worthwhile things that settlement money could do on reservations desperately in need of economic development. Terminationists, however, saw it as a final settlement between old antagonists so that no controversies over past dealings with Indians would linger after tribes were terminated. Truman worried about the cost of the ICC process. The inflationary economy of the postwar years created strong pressure to reduce federal expenditures. The conservative Eightieth Congress twice came close to overriding presidential vetoes of tax reduction bills and would not accept any spending increases. But when Wyoming Democratic Representative Joseph O'Mahoney, chair of the House Committee on Interior and Insular Affairs, convinced Truman that the claims bill would reduce BIA expenditures over the long term, Truman backed the measure and ensured its passage. ${ }^{52}$

52. Nancy O. Lurie, "The Indian Claims Commission," Annals of the American Academy of Political and Social Science 436 (1978), 97-110; John T. Vance, "The Congressional Mandate and the Indian Claims Commission," North Dakota Law Review 45 (1969), 325-36; Harry S. Truman, "Statement by the President upon Signing Bill Creating the Indian Claims Commission," 8/13/1946, Public Papers of Harry Truman, 1946 (Washington, DC, 1962), 414; Arthur Watkins, "Termination of Federal Supervision: The Removal of Restrictions over Indian Property and Person," Annals of the American Academy of Political and Social Science 311 (1957), 50. The bill gave the impression of bipartisan agreement on Indian policy. Some historians refer to a Congress in the last half of the 1940s with "a consensus" or "a bipartisan movement between Truman Democrats and conservative Republicans" or to "liberalism changing from supporting traditional community to finding community in the nation." Those would be accurate descriptions only in the loosest sense since there was little collaboration or central coordination, and no one pushed any policy very hard. See Bernstein, American Indians and World War II, 159; Thomas W. Cowger, The National Congress of American Indians: The Founding Years (Lincoln, NE, 1999), 51; and Clayton R. Koppes, "From New Deal to Termination: Liberalism and Indian Policy, 1933-1953," Pacific Historical Review 46 (1977), 543-66. 
The elimination of budgetary concerns allowed President Truman to support the Indian Claims Commission bill based on his growing sense of justice and advancing civil rights. The divide in the Democratic Party on civil rights, however, muted the issue even after the Democrats regained control of Congress in the 1948 election. In Indian affairs, Democrats promoted no alternative to termination, but their leadership of key congressional committees kept tribal termination bills from getting beyond committee action.

When Republicans reclaimed control of both the White House and the Congress in the 1952 election, terminationists again attempted to forge ahead with their agenda. Through the early 1960s, Congress passed 14 bills terminating 109 tribes. The terminationists' success was more limited than the numbers suggest, though. Many Indians did not want termination, and most of the terminated tribes were small, representing only 3 percent of the Indian population and 3.2 percent of land in trust. In some cases, the Indians involved were largely assimilated and favored the change. For most others, Congress later restored their tribal status. ${ }^{53}$

As Indians around the country united and developed the means to make their voices heard, liberals, some moderates, and a few conservatives in Congress came to support a more Indian-defined type of self-determination on reservations. Some congressmen, such as Democratic Senator Frank Church of Idaho, continued to promote termination into the mid-1960s. But most came to see that civil rights for Indians should include consideration of tribal rights as well as individual U.S. citizenship rights. Although Indians would certainly not win everything they wanted from Congress, the stage was set for the federal policies of self-determination in President John F. Kennedy's New Frontier and President Lyndon Johnson's Great Society. ${ }^{54}$

53. Charles F. Wilkinson and Eric R. Biggs, "The Evolution of the Termination Policy," American Indian Law Review 5 (1977), 148-51.

54. See George Pierre Castile, To Show Heart: Native American Self-Determination and Federal Indian Policy, 1960-1975 (Tucson, AZ, 1998); and Thomas Clarkin, Federal Indian Policy in the Kennedy and Johnson Administrations, 1961-1969 (Albuquerque, NM, 2001). 
President Truman did not live long enough to see the outcome of his well-intentioned but contradictory Indian policies. $\mathrm{He}$ had not sided with terminationists in Congress, largely because of opposition from Indians or the Department of the Interior. Neither was he aware of the policy void caused by inattention and confusion that would allow better organized terminationists to shape Indian policy. He had acted on behalf of individual civil rights for Indians and the rights of particular tribes. Like many Americans, he saw no distinction between the two. ${ }^{55}$

Truman's Committee on Civil Rights recognized the history of Indian self-government and addressed the issue of tribal rights in its deliberations. However, in its final report, To Secure These Rights, the only mention of particular Indian rights involved violations of U.S. citizenship rights, as when Arizona and New Mexico denied Indians the right to vote. Even those examples were included in a long list of violations experienced by many minority groups. ${ }^{56}$

Terminationists used some of the same rhetoric as the civil rights movement-terms such as emancipation, freedom, and liberation. To further confuse matters, Truman shared much of the terminationists' disdain for the BIA. Although "the Government created Indian bureaus for the alleged protection of Indian rights," he wrote, "every one of our Indian bureaus in Washington was saddled with crooks and cheats." But the reasons for his anti-BIA sentiments were different than those of terminationists. Instead of seeing the bureau as an obstacle to Indians mixing and competing with the mainstream, he saw it as a big part of the historic violation of Indian rights. ${ }^{57}$

In Where the Buck Stops, Truman devoted a seven-page chapter to Indians. All but the last two paragraphs decried the historic mistreatment of Indians. As an avid reader of history, he was knowledgeable about Indian history and showed sympa-

55. In another example of Truman defending tribal rights, the president nixed a bill for Alaska statehood because of Indian opposition to provisions concerning native possessory claims. See Philp, Termination Revisited, 46-49.

56. Robert K. Carr, executive secretary, memo to members of the President's Committee on Civil Rights, 6/6/1947, Committee Documents, folder: Indians, Civil Rights of, Truman Papers.

57. Harry S. Truman, Where the Buck Stops: The Personal and Private Writings of Harry S. Truman (New York, 1989), 285. 
thy for wrongs committed against tribes as well as individual Indians. But he did not address his own policies, except that he "tried to look after Indian rights all the time I was president." For evidence, he offered a couple of instances when he vetoed bills that he felt exploited Indians. Although he was willing to use the power of the federal government to champion civil rights, he never understood Indian status sufficiently to conceive that his own policies needed to go beyond just defending certain tribes when Congress tried to perpetrate an injustice and beyond occasional moves in defense of individual Indian rights, such as those of Sergeant Rice. ${ }^{58}$

THE RICE CONTROVERSY that so vividly resembled the broader civil rights movement's struggle to break down segregation also underscored the uncertainties of Indian status and identity in postwar American life. John Rice, sharing in the nationalism of the era, took great pride in being an American soldier. $\mathrm{He}$ had never rejected his Indian identity, but neither did he embrace it in the way many Indians later did during and after the Red Power and self-determination movements of the 1960s and 1970s.

Despite the paradox of Truman's Indian civil rights policies, Winnebagoes appreciated Truman's role in the John Rice incident. At the 119th Annual Winnebago Powwow in July 1985, Frank LaMere, executive director of the Nebraska Inter-Tribal Development Corporation, honored the memory of President Truman and the Winnebago veterans of the Korean War. A month later, Winnebago artist Charles Raymond III (a cousin of John Rice), along with 20 other tribal members, traveled to Independence, Missouri, to take part in a ceremony at the Truman Presidential Library, where they presented a drawing depicting Sergeant Rice with President Truman in the background. "President Truman's action demonstrated another part of his greatness," one participant commented. "We Indians of every tribe take pride in what Truman did. He represented all the Indian people." ${ }^{\prime 59}$

58. Ibid., 281-88.

59. Tribute given by Frank LaMere at the 119th Annual Winnebago Powwow in Winnebago, Nebraska, 7/28/1985, vertical file, Truman Papers; Truman Presidential Library Press Release, "Indians present drawing to Truman Library," 8/19/1985, ibid. 


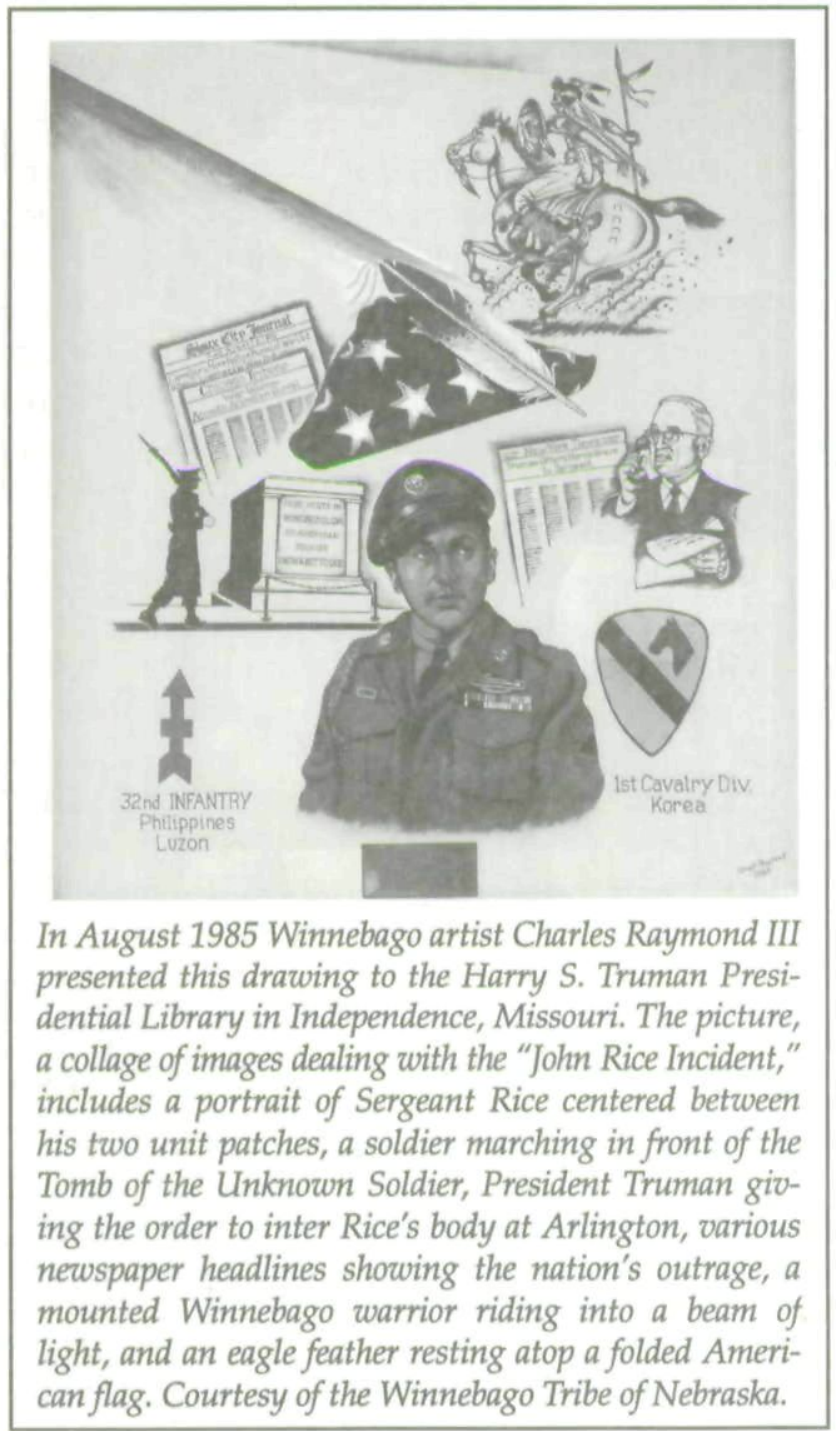

The John Rice incident also helped the people of Sioux City to confront the less savory aspects of its past. Over time residents became more accepting of racial and ethnic diversity. On the fiftieth anniversary of the incident, the Winnebago tribe and Sioux City worked together on a public memorial. Several hundred people gathered at Veteran's Park in Sioux City to hear 
Mayor Marty Dougherty and Winnebago Tribal Council Chairman John Blackhawk honor John Rice. Part of the ceremony was traditional as well. Tribal representatives placed a colored blanket around Evelyn Rice as she stood at the drumming circle that closed the ceremony. Indian activist Frank LaMere had been invited but could not attend. Instead, he sent a message read at the ceremony in which he said, "We have come far at the expense of Sergeant John Rice and the Gold Star family he left behind. Our respect for one another this day is their legacy and speaks to the possibilities. The bridges we can build tomorrow will be strong if we do not forget that the foundation was laid on a battlefield in Korea." ${ }^{\prime 60}$

In 2004 the Winnebago Tribal Council received a letter from 87-year-old Edward Krischel-the army bugler assigned to John Rice's burial detail. He had remained with the detail, serving as honor guard all the way to Arlington National Cemetery. After the Arlington funeral, Evelyn Rice gave him the American flag she had received during the Sioux City burial. Honored, Krischel kept the flag for the next 50 years. The purpose of his 2004 letter was to inquire if the tribe or the local American Legion post would like to have the flag. At the July 2004 Winnebago Powwow, Evelyn Rice and her children, along with relatives, friends, and veterans, acknowledged the return of the flag, which was brought out by the American Legion post as the Hard River Singers rendered an honor song. The Winnebago tribe always regarded Sergeant John Rice as a hero, and that honor was also extended to his wife. Six months later, Evelyn Rice died in Sioux City. She had been so scarred by the burial experience that she had refused to talk about it thereafter, even to her children. According to Winnebago Tribe Vice Chairman Jim Snow, she "never wanted to be in the spotlight, but her integrity and love for the memory of her husband sustained her." ${ }^{161}$

60. A year later, Avery Brothers Sign Company and the Sioux City Public Museum put up a billboard in downtown Sioux City with a picture of Rice that informed the public that Rice had been recently included on the city's history Web site. See Sioux City Journal, 8/29/2001; "Sergeant John R. Rice," Sioux City History, Notable People, www.siouxcityhistory.org/people/ more.php?id=3_0_2_0_M.

61. Jim Snow, vice chairman, Winnebago Tribe of Nebraska, to Tom Britten, 2/11/2005; Omaha World-Herald, 1/28/2005. 
Copyright of Annals of Iowa is the property of State of Iowa, by \& through the State Historical Society of Iowa and its content may not be copied or emailed to multiple sites or posted to a listserv without the copyright holder's express written permission. However, users may print, download, or email articles for individual use. 